UDK 631.461.5:633.34

\title{
Evaluation of the effect of symbiotic nitrogen fixation on the yield of soybean and nitrogen state of soil
}

\section{A. V. Revtie-Uvarova}

NSC «Institute for Soil Science and Agrochemistry Research named after O. N. Sokolovsky», Kharkiv, Ukraine

\begin{tabular}{|c|c|}
\hline ARTICLE INFO & ABSTRACT \\
\hline $\begin{array}{l}\text { Received } 29.03 .2019 \\
\text { Received in revised form } \\
02.05 .2019 \\
\text { Accepted } 19.08 .2019 \\
\text { Available online } 01.09 .2019 \\
\text { Keywords: } \\
\text { chernozem typical; } \\
\text { nitrogen; } \\
\text { inoculation; } \\
\text { mineral nitrogen reserves; } \\
\text { soybean plants development; } \\
\text { symbiotic nitrogen fixation; }\end{array}$ & $\begin{array}{l}\text { Under the conditions of the low-field experiment on chernozems typical low humus, it } \\
\text { was estimated the agronomic efficiency of symbiotic nitrogen fixation for growing } \\
\text { soybean by comparing indicators of soil condition and morphometric characteristics of } \\
\text { soybean plants, the seeds of which were treated with a preparation based on nodule } \\
\text { bacteria Bradyrhizobium japonicum with untreated seeds (non-inculcated). It was } \\
\text { established that symbiotic nitrogen fixation contributes to the formation of a more } \\
\text { powerful root system with active nodules, an increase in the growth in intensity of } \\
\text { growth of the vegetative mass by } 42 \% \text {, and an improvement in the supply of nitrogen } \\
\text { to soybean plants, as assessed by chlorophyll content in leaves. The yield of soybean } \\
\text { grain increases by } 29 \% \text {, which, like vegetative mass and roots, contains more nitrogen } \\
\text { and is characterized by a tendency to a decrease in the content of phosphorus and } \\
\text { potassium. It was determined that against the background of a decrease in the ratio of } \\
\text { secondary products to soybean grain (1.5: } 1 \text { ), nitrogen removal with vegetative mass } \\
(2.2 \text { times) and grain (by } 32 \% \text { ) are increased. It was established that part of the } \\
\text { biologically fixed nitrogen in the formation of the biological yield of soybean obtained on } \\
\text { chernozem typical under the weather conditions of } 2018 \text { is } 43 \% \text {, and the available soil } \\
\text { nitrogen is } 57 \% \text {. To diagnose the availability of soil with nitrogen in the aftereffect of } \\
\text { symbiotic nitrogen fixation, it is proposed to determine the «net» nitrogen-fixation by the } \\
\text { actual reserves of mineral nitrogen under inoculated soybean (minus its reserves under } \\
\text { non-inoculated) and by the potential amount of nitrogen that additionally comes with the } \\
\text { total vegetative mass (by the difference between the nitrogen content of vegetative } \\
\text { mass inoculated and non-inoculated soybean). In the weather conditions of } 2018 \text { in the } \\
\text { typical chernozem «net» nitrogen fixation under soybean was } 69 \mathrm{~kg} \mathrm{~N} / \mathrm{ha} \text {, of which } 40 \\
\mathrm{~kg} / \mathrm{ha} \text { are the reserves of mineral nitrogen in the soil and } 29 \mathrm{~kg} / \mathrm{ha} \text { are nitrogen coming } \\
\text { from the vegetative mass. }\end{array}$ \\
\hline
\end{tabular}

Citing: Revtie-Uvarova A.V. 2019. Evaluation of the effect of symbiotic nitrogen fixation on the yield of soybean and nitrogen state of soil. Agrochemistry and Soil Science. Collected papers. No. 88. Kharkiv: NSC ISSAR, P. 79-88. DOI: https://doi.org/10.31073/acss88-11.

\section{References}

1. Umarov M.M., Kurakov A.V., Stepanov A.L. 2007. Microbiological transformation of nitrogen in the soil. Moscow GEOS. 138 p. (Rus.).

2. Altobelli F., Amanullah, Benedetti A., Calles T., Caon L., Charrondiere R., Giri S.P., Grande F., Muthuraman R.P., Pisante M., Pramar B., Vargas R., Verma D., Vishwakarma A. K., Wiese L., Xipsiti M. 2016. Soils and pulses: Symbiosis for life. Rome: FAO, 104 p. URL: http://www.fao.org/3/a-i6437e.pdf.

3. Volobueva O. G. 2011. Symbiotic nitrogen fixation as a factor of ecological safety and soil fertility. Vestnyk RUDN. No 1. P. 53-60. (Rus.).

4. Patyka V.P., Gnatjuk T.T., Buleca N.M., Kyrylenko L.V. 2015. Biological nitrogen in the system of agriculture. Zemlerobstvo. V. 2. P. 12-20. (Ukr.).

5. Morgun V.V., Kots S.Ja. 2018. Biological nitrogen on present agriculture. Plant Varieties Studying and Protection. Vol. 14, No 3. P. 285-294. DOI: 10.21498/2518-1017.14.3.2018.145293. (Ukr.).

6. Volkogon V.V., Sal'nyk V.P. 2005. The importance of growth regulators in the formation of active nitrogen fixing symbiosis and associations. Fiziologija i biohimija kul'turnyh rastenij. No 3. P. 187-197. (Ukr.).

7. Kots S. Ja. 2011. The current state of research on the biological fixation of nitrogen. Fiziologija $i$ biohimija kul't. rastenij. Vol. 43, No 3. P. 212-225. (Ukr.). URI: http:// dspace.nbuv.gov.ua/handle/123456789/66368.

8. Pervachuk M. V., Vradij O. I. 2016. Intensification of the process of fixation of atmospheric nitrogen under the influence of microbial preparations on crops of perennial legumes. Sil's'ke gospodarstvo ta lisivnyctvo. No 4. P. 220-230. (Ukr.). URL: http://socrates.vsau.org/repository/getfile.php/15746.pdf.

9. Babych A. O., Babych-Poberezhna A. A. 2011. Selection, production, trade and use of soybeans in the world. Kyiv: Agrarna nauka. 548 p. (Ukr.).

10. Plant Growing of Ukraine : Statistical Collection 2017. 2018. Kyiv. 222 p. URL: http://www.ukrstat.gov.ua/. (Ukr.).

11. Provorov N. A., Simarov B. V. 1992. Genetic polymorphism of legumes on the ability to symbiosis with nodule bacteria. Genetika. Vol. 28, No 6. P. 5-14. (Rus.).

12. Gamajunova V. V., Nazarchuk A. A. 2013. Formation of soybean productivity depending on variety, mineral nutrition and seed treatment with biopreparations in southern Ukraine. Agropromyslove vyrobnyctvo Polissja. V. 6. P. 70-73. (Ukr.).

13. Posypanov G. S., Kobozeva T. P., Tazin I. I., Beljaev E. V., Delaev U. A. 2006. Modern methods for determining the amount of fixed nitrogen in the field. Izvestija TSHA. V. 2. P. 129-134. (Rus.). 
14. Didora V.G., Stupnic'ka O. ., Didora L.D. 2015. The effectiveness of symbiotic activity of soybean crops in the conditions of the Polissya of Ukraine. Bulletin of Agricultural Science. No 8. P. 56-60. (Ukr.). URL: http://agrovisnyk.com/archive ua 201508 11.html

15. Zoundji C. C., Houngnandan P., Kouelo F. A., F. E. Boko, J. J. Adu Gyamfi. January 2016. Symbiotic nitrogen fixation and nitrogen budget of Brazilian soybean [Glycine max (L.) Merril] varieties introduced in Benin using ${ }^{15} \mathrm{~N}$ isotopic dilution method. African Journal of Agricultural Research. https://www.researchgate.net/publication/290449458_Symbiotic_nitrogen_fixation_and_nitrogen_budget_of_Brazilian_soybea n_Glycine_max_L_Merril_varieties_introduced_in_Benin_using_15N_isotopic_dilution_method.

16. Petrychenko V. F., Sereda L. M. 2000. Features of formation of soybean productivity depending on hydrothermal resources and influence of agrotechnical measures. Zb. naukovyh prac' Vinnyc'kogo derzhavnogo agrarnogo universytetu. V. 8. T. 1. P. 53-57. (Ukr.).

17. Zabolotnyi G. M., Cygansyij V. I., Cygans'ka O. I. 2015. Symbiotic productivity of soybeans depending on the level of fertilization in the right-bank forest-steppe. Zbirnyk naukovyh prac' NNC «Instytut zemlerobstva NAAN». Vyp. 4. P. 66-71. (Ukr.). URL: http://nbuv.gov.ua/UJRN/znpzeml 2015411. (Rus.).

18. Trepachev E. P. 1981. About methods of study of nitrogen-fixing capacity of legumes. Agrohimija. No 12. P. 129-141.

19. Posypanov G.S. 1991. Determination of the quantity of fixed nitrogen of air in the field. In the book: Methods of studying the biological fixation of nitrogen in air. Moscow: Agropromizdat. P. 27-30. (Rus.)

20. Dotsenko O.V., Solokha M.O., Nikonenko V. ., Vinnichenko L. M. 2018. Recommendations for operational evaluation and correction of nitrogen supply of basic cereal crops under production conditions with the use of terrestrial and remote methods of plant diagnostics. Kharkiv. 24 p. (Ukr.).

21. Soil quality. Determination of nitrate and ammonium nitrogen in modification of NSC ISSAR named after O.N. Sokolovsky : DSTU 4729:2007. 2007. [Existing with 2008-01-01]. Kyiv: Derzhcpozhyvstandart Ukraine. 14 p. (Ukr.).

22. Plants. Determination of common forms of nitrogen, phosphorus, potassium in one stress of vegetative material : MVV 31-497058-019-2005. 2005. In: Methods of determining the composition and properties of soils. Book 2. Kharkiv. Drukarnja No 13. P. 189-208. (Ukr.).

23. Judin F.A. 1971. Methodology of agrochemical research. Moscow: Kolos. 271 p. (Rus.).

24. Hvorova L. ., Topazh A.G., Abramova A.V., Neupokoeva K.G. 2015. Approaches to the description of symbiotic nitrogen fixation. Part 1. Analysis and selection of a list of factors with an assessment of their priority. Izvestija Altajskogo gosudarstvennogo universiteta. No 1/1 (85). P. 187-191. (Rus.). DOI: 10.14258/izvasu(2015)1.1-34.

25. Bahmat O.M. 2012. Simulation of adaptive technology of soybean cultivation [monograph]. Kam'janets-Podil's'ky]. 436 p. (Ukr.).

26. Prokopchuk S.V. 2017. Efficiency of application of nitrogen fertilizers and bacterial preparations for soy. In: Symbiotic nitrogen fixation and crop. Uman: «Sochins'kyj M. M.». P. 217-259. (Ukr.).

27. Zimmer S., Messmer M., Haase Th. Piepho H.-P., Mindermann A., Schulz H., Habekuß A., Ordon F., Wilbois K.-P., $\mathrm{Heß}$ J. 2016. Effects of soybean variety and Bradyrhizobium strains on yield, protein content and biological nitrogen fixation under cool growing conditions in Germany. Europ. J. Agronomy. № 72. P. 38-46. DOI: 10.1016/j.eja.2015.09.008.

28. Coskan A., Dogan K. 2011. Symbiotic Nitrogen Fixation in Soybean. Soybean Physiology and Biochemistry. P. 167182. DOI: $10.5772 / 20073$.

29. Tamiru S., Lalit M. P., Tsige A. 2012. Effects of Inoculation by Bradyrhizobium japonicum Strains on Nodulation, Nitrogen Fixation, and Yield of Soybean (Glycine max L. Merill) Varieties on Nitisols of Bako, Western Ethiopia. ISRN Agronomy. Vol. 2012, Article ID 261475, 8 pages. DOI: 10.5402/2012/261475.

30. Long S.R. 1996. Rhizobium symbiosis: Nod factors in perspective. Plant Cell. № 8. P. 1885-1898. DOI: 10.1105/tpc.8.10.1885.

31. Mus F., CrookM.B., Garcia K., Garcia Costas A., Geddes B.A., Kouri E.D., Paramasivan P., Ryu M. H., Oldroyd G. E. D., Poole P. S., Udvardi M. K., Voigt C. A., Ane J. M., Peters J.W. 2016. Symbiotic nitrogen fixation and the challenges to its extension to nonlegumes. Appl Environ Microbiol. № 82. P. 3698-3710. DOI: 10.1128/AEM.01055-16.

32. Serova A.T., Cyganov V.E. 2014. Aging of the symbiotic nodule in legume plants: molecular genetic aspects. Sel'skohozjajstvennaja biologija. No 5 P. 3-15. (Rus.). DOI: 10.15389/agrobiology.2014.5.3rus .

33. Leggett M., Diaz-Zorita M.,Koivunen M.,Bowman R.,Pesek R., Stevenson C.,Leister T. 2017. Soybean Response to Inoculation with Bradyrhizobium japonicum in the United States and Argentina. Agronomy Journal. Vol. 109. No 3. P. 10311038. DOI: 10.2134/agronj2016.04.0214.

34. Netis V.I. 2018. Formation of elements of soybean productivity for different growing practices. Tavrijs'kyj naukovyj visnyk. Vyp. 99. P. 100-107. (Ukr.).

35. Babych A.O. 1998. Soybeans for health and life on planet Earth. Kyiv: Agrarna nauka. 272 c. (Ukr.).

36. Podobedov A. V. Tarushkin V. I., Sajko V. F. 1998. World soybean production. Agrarna nauka. No 6. C. 12-15. (Rus.).

37. Salvagiotti F., Cassman K. G., Specht J. E., Waltersa D. T., Weissb A., Dobermanna A. 2008. Nitrogen uptake, fixation and response to fertilizer N in soybeans: A review. Field Crops Research. No 108 (1). P. 1-13. DOI: 10.1016/j.fcr.2008.03.001.

38. Ogurcov Je. M., Myhjejev V. G., Bjelins'kyj Ju. V., Klymenko I. V. 2016. Adaptive Soybean Growing Technology in the Eastern Forest-Steppe of Ukraine: [monograph]. Ed. by Bobro M. A. Kharkiv: Machulin. 272 p. (Ukr.).

39. Soil quality. Fertility indexes of soils : DSTU 4362:2004. 2006. [Existing with 2006-01-01]. Kyiv : Derzhcpozhyvstandart Ukrai'ny. 22 p. (Ukr.).

40. Azarov B. F., Akulov P. G., Azarov V. B., Solovichenko V. D. 2008. Contribution of the symbiotic nitrogen of legumes in the fertility of the soils of the central black earth. Dostizhenija nauki i tehniki APK. No 9. P. 9-11. (Rus.).

УДК 631.461.5:633.34

Оцінка впливу симбіотичної азотфіксації на продуктивність рослин сої та азотний стан ґрунту

\section{А. В. Ревтьє-Уварова}

ННЦ «Інститут ґрунтознавства та агрохімії імені О.Н. Соколовського», Харків, Україна 


\begin{tabular}{l}
\hline \multicolumn{1}{c}{ ІНФОРМАЦІЯ } \\
\hline Отримано 29.03.2019 \\
Отримано після \\
доопрацювання \\
02.05.2019 \\
Затверджено до друку \\
19.08.2019 \\
Доступно онлайн \\
01.09.2019 \\
\hline
\end{tabular}

Ключові слова:

азот;

запаси мінерального

азоту;

інокуляція;

розвиток рослин сої;

симбіотична

азоторіксаиія;

чорнозем типовий

АНОТАЦІЯ

В умовах польового дрібноділянкового досліду на чорноземі типовому малогумусному оцінено агрономічну ефективність симбіотичної азотфіксації за вирощування сої шляхом порівняння індикаторів стану ґрунту та морфометричних характеристик рослин, насіння яких перед сівбою було оброблене інокулянтом на основі вірулентних штамів бульбочкових бактерій Bradyrhizobium japonicum, з варіантами з необробленим насінням. Встановлено, що симбіотична азотфіксація сприяє фрормуванню більш потужної кореневої системи з активними бульбочками, збільшенню на $42 \%$ інтенсивності наростання вегетативної маси та поліпшенню забезпеченості рослин сої азотом, оціненого за вмістом хлорофілу в листях. Підвищується на 29 \% урожайність зерна, яке містить, як і листостеблова маса та корені, більше азоту та характеризується тенденцією до зниження вмісту фосфору та калію. Визначено, що на фоні зменшення відношення побічної продукції до зерна сої (1,5:1) збільшується винос азоту на формування як листостеблової маси (в 2,2 раза), так і зерна (на 32 \%). Встановлено, що частка біологічно фіксованого азоту, винесеного з біологічним урожаєм сої з гектару площі, становить $43 \%$, азот ґрунту становить $57 \%$. Для діагностики забезпеченості ґрунту азотом у післядії симбіотичної азотфіксації пропонується визначати «нетто» азотфіксації за фрактичними запасами мінерального азоту у ґрунті під інокульованою соєю (за мінусом його запасів під неінокульованою) та за потенційною кількістю азоту, який надходить додатково 3 загальною листостебловою масою (за різницею між вмістом азоту в листостебловій масі інокульованої та неінокульованої сої). В погодних умовах 2018 року на чорноземі типовому «нетто» азотфіксації під соєю становило 69 кг N/га, з яких 40 кг/га - запаси мінерального азоту в ґрунті та 29 кг/га - азот, що надходить із листостебловою масою.

*E-mail: alina_rev@meta.ua

Форма цитування: Revtie-Uvarova A.V. Evaluation of the effect of symbiotic nitrogen fixation on the yield of soybean and nitrogen state of soil. Agrochemistry and Soil Science. Collected papers. 2019. No. 88. Kharkiv: NSC ISSAR, P. 79-88. DOI: https://doi.org/10.31073/acss88-11

\section{Список використаних джерел}

1. Умаров М. М., Кураков А. В., Степанов А. Л. Микробиологическая трансформация азота в почве. Москва: ГEOC, 2007. $138 \mathrm{c}$.

2. Soils and pulses : Symbiosis for life / F. Altobelli, K. Amanullah, A. Benedetti [et al.]. Rome : FAO, 2016. 104 pp. URL : http://www.fao.org/3/a-i6437e.pdf.

3. Волобуева О.Г. Симбиотическая азотфиксация как фрактор экологической безопасности и плодородия почвы. Вестник РУДН. 2011. № 1. С. 53-60.

4. Біологічний азот у системі землеробства / В.П. Патика, Т. Т. Гнатюк, Н.М.Булеца, Л.В.Кириленко. Землеробство. 2015. Вип. 2. С. 12-20.

5. Моргун В. В., Коць С. Я. Біологічний азот у сучасному сільськогосподарському виробництві. Plant Varieties Studying and Protection. 2018. Vol. 14, № 3. C. 285-294. URL : https://doi.org/10.21498/2518-1017.14.3.2018.145293.

6. Волкогон В. В., Сальник В.П. Значення регуляторів росту у формуванні активних азотфіксувальних симбіозів та асоціацій. Физиология и биохимия культ. растений. 2005. № 3. С. 187-197.

7. Коць С. Я. Сучасний стан досліджень біологічної фріксації азоту. Физиология и биохимия культ. растений. 2011. T. 43, № 3. C. 212-225. URI: http:// dspace.nbuv.gov.ua/handle/123456789/66368.

8. Первачук М. В., Врадій О. І. Інтенсифрікація процесу фріксації атмосфрерного азоту під впливом мікробних препаратів на посівах багаторічних бобових трав. Сільське господарство та лісівництво. 2016. № 4. С. $220-230$. URL: http://socrates.vsau.org/repository/getfile.php/15746.pdf.

9. Бабич А. О., Бабич-Побережна А. А. Селекція, виробництво, торгівля і використання сої у світі. Київ: Аграрна наука, 2011. 548 с.

10 Рослинництво України : [статистичний збірник 2017]. Київ, 2018. 222 c. URL : http://www.ukrstat.gov.ua/.

11. Проворов Н. А., Симаров Б. В. Генетический полиморфизм бобовых культур по способности к симбиозу с клубеньковыми бактериями. Генетика. 1992. Т. 28. № 6. С. 5-14.

12. Гамаюнова В. В., Назарчук А. А.Формування продуктивності сої залежно від сорту, мінерального живлення та обробки насіння біопрепаратами на півдні України. Агропромислове виробництво Полісся. 2013. Вип. 6. С. 70-73.

13. Современные методы определения количества фиксированного азота воздуха в полевых условиях. Г. С. Посыпанов, Т. П. Кобозева, И. И. Тазин [и др.]. Известия ТСХА. 2006. Вып. 2. С. 129-134.

14. Дідора В. Г., Ступніцька О. С., Дідора Л. Д. Ефективність симбіотичної діяльності посівів сої в умовах Полісся України. Вісник аграрної науки. 2015. № 8. C. 56-60. URL: http://agrovisnyk.com/archive ua 201508 11.htm

15. Symbiotic nitrogen fixation and nitrogen budget of Brazilian soybean [Glycine max (L.) Merril] varieties introduced in Benin using ${ }^{15} \mathrm{~N}$ isotopic dilution method. C. C. Zoundji, P. Houngnandan, F. A. Kouelo [et al.]. African $\begin{array}{llllll}\text { Journal of Agricultural Research. } & \text { January } & \text { P. 7-15. } & \text { URL: }\end{array}$ https://www.researchgate.net/publication/290449458_Symbiotic_nitrogen_fixation_and_nitrogen_budget_of_Brazilian_soyb ean_Glycine_max_L_Merril_varieties_introduced_in_Benin_using_15N_isotopic_dilution_method.

16. Петриченко В. Ф., Середа Л. М. Особливості формування продуктивності сої залежно від гідротермічних ресурсів та впливу агротехнічних заходів. Зб. наукових праць Вінницького державного аграрного університету. 2000. Вип. 8, Т. 1. С. 53-57. 
17. Заболотний Г. М., Циганський В. І., Циганська О. І. Симбіотична продуктивність сої залежно від рівня удобрення в правобережному Лісостепу. Збірник наукових праць ННЦ «/нститут землеробства НААН». 2015. Вип. 4. С. 66-71. URL: http://nbuv.gov.ua/UJRN/znpzeml 2015411.

18. Трепачев Е. П. О методах исследования азотфиксирующей способности бобовых культур. Агрохимия. 1981. № 12. С. 129-141.

19. Посыпанов Г.С. Определение количества фиксированного азота воздуха в полевых условиях. В кн. : Методы изучения биологической фиксации азота воздуха (справочное пособие). Москва: Агропромиздат, 1991. C. $27-30$.

20. Рекомендації щодо оперативного оцінювання та корегування азотного живлення основних зернових культур у виробничих умовах із залученням наземних і дистанційних методів рослинної діагностики / О. В. Доценко, М. О. Солоха, В. М. Ніконенко [та ін.]. Харків: Стиль-Издат, 2018. 24 с.

21. Якість ґрунту. Визначання нітратного і амонійного азоту в модифікації ННЦ ІГА імені О. Н. Соколовського : ДСТУ 4729:2007. [Чинний з 2008-01-01]. Київ: Держспоживстандарт України, 2007. 14 с.

22. Рослини. Визначення загальних форм азоту, фосфору, калію в одній наважці рослинного матеріалу: MBВ 31-497058-019-2005. Методики визначення складу та властивостей ґрунтів. Харків: Друкарня № 13 , 2005. КH. 2. C. 189-208.

23. Юдин Ф.А. Методика агрохимических исследований. Москва: Колос, 1971. 271 с.

24. Подходы к описанию симбиотической азотфиксации. Часть 1. Анализ и выделение перечня факторов с оценкой их приоритетности / Л. А. Хворова, А.Г. Топаж, А. В. Абрамова, К.Г. Неупокоева. Известия Алтайского государственного университета. 2015. № 1/1 (85). C. 187-191. DOI: 10.14258/izvasu(2015)1.1-34

25. Бахмат О.М. Моделювання адаптивної технології вирощування сої [монографія]. Кам'янецьПодільський, 2012. 436 с.

26. Прокопчук C.B. Ефективність застосування азотних добрив і бактеріальних препаратів під сою. В кн. : Симбіотична азотфіксація та врожай. Умань: Сочінський М. М., 2017. С. 217-259.

27. Effects of soybean variety and Bradyrhizobium strains on yield, protein content and biological nitrogen fixation under cool growing conditions in Germany / S. Zimmer, M. Messmer, Th. Haasec [et al.]. Europ. J. Agronomy. 2016. № 72. P. 38-46. DOI: http://dx.doi.org/10.1016/j.eja.2015.09.008.

28. Coskan A., Dogan K. 2011. Symbiotic Nitrogen Fixation in Soybean. Soybean Physiology and Biochemistry. 2011. P. 167-182. DOI: http://dx.doi.org/10.5772/20073.

29. Tamiru S., Lalit M.P., Tsige A. Effects of Inoculation by Bradyrhizobium japonicum Strains on Nodulation, Nitrogen Fixation, and Yield of Soybean (Glycine max L. Merill) Varieties on Nitisols of Bako, Western Ethiopia. ISRN Agronomy Vol. 2012, Article ID 261475, 8 pages. URL : http://dx.doi.org/10.5402/2012/261475.

30. Long S.R. Rhizobium symbiosis: Nod factors in perspective. Plant Cell. 1996. № 8. P. 1885-1898. URL : http://dx.doi.org/10.1105/tpc.8.10.1885.

31. Symbiotic nitrogen fixation and the challenges to its extension to nonlegumes / F. Mus, M. B. Crook, K. Garcia [et al.]. Appl Environ Microbiol. 2016. № 82. P. 3698-3710. URL : doi:10.1128/AEM.01055-16.

32. Серова А.Т., Цыганов В.Е. Старение симбиотического клубенька у бобовых растений: молекулярногенетические аспекты. Сельскохозяйственная биология. 2014. № 5 C. 3-15. DOI: 10.15389/agrobiology.2014.5.3rus.

33. Soybean Response to Inoculation with Bradyrhizobium japonicum in the United States and Argentina / M. Leggett, M. Diaz-Zorita, M. Koivunen [et al.]. Agronomy Journal. 2017. Vol. 109. № 3. P. $1031-1038$. URL: doi:10.2134/agronj2016.04.0214.

34. Нетіс В. І. Формування елементів продуктивності сої за різних заходів вирощування. Таврійський науковий вісник. 2018. Вип. 99. С. 100-107.

35. Бабич А. О. Соя для здоров'я і життя на планеті Земля. Київ: Аграрна наука, 1998. 272 с.

36. Подобедов А. В. Тарушкин В. И., Сайко В. Ф. Мировое производство сои. Аграрна наука. 1998. № 6. С. 12-15.

37. Nitrogen uptake, fixation and response to fertilizer $\mathrm{N}$ in soybeans: A review / F. Salvagiotti, K. G. Cassman, J. E. Specht [et al.]. Field Crops Research. 2008. № 108 (1). P. 1-13. URL : doi: 10.1016/j.fcr.2008.03.001.

38. Адаптивна технологія вирощування сої у східному Лісостепу України: [монографія] / Є.М. Огурцов, В.Г. Михєєв, Ю.В. Бєлінський, І.В. Клименко // за ред. М.А. Бобра. Харків: Мачулін, 2016. 272 с.

39. Якість ґрунту. Показники родючості ґрунтів: ДСТУ 4362:2004. [Чинний 3 2006-01-01]. Київ : Держспоживстандарт України, 2006. 22 с.

40. Вклад симбиотического азота бобовых в плодородие почв центрального черноземья. Б. Ф. Азаров, П. Г. Акулов, В. Б. Азаров, В. Д. Соловиченко. Достижения науки и техники АПК, 2008. № 9. С. 9-11.

Удк 631.461.5:633.34

Оценка влияния симбиотической азотфиксации на продуктивность растений сои и азотное состояние почвы

\section{А. В. Ревтье-Уварова}

ННЦ «Институт почвоведения и агрохимии имени А. Н. Соколовского», Харьков, Украина; E-mail: alina_rev@meta.ua.

В условиях полевого мелкоделячночного опыта на черноземе типичном малогумусном оценили агрономическую эффективность симбиотической азотфиксации при выращивании сои путем сравнения индикаторов состояния почвы и морфометрических характеристик растений, семена которых перед посевом были обработаны инокулянтом на основе вирулентных штаммов клубеньковых бактерий Bradyrhizobium јаропicum, с вариантами с необработанными семенами. Установлено, что симбиотическая азотфиксация способствует фрормированию более мощной корневой системы с активными клубеньками, увеличению на 42 \% интенсивности нарастания вегетативной массы и улучшению обеспеченности растений сои азотом, оцененному по содержанию 
хлорофилла в листьях. Повышается на 29 \% урожайность зерна, которое содержит, как и листостебельная масса и корни, больше азота и характеризуется тенденцией к снижению содержания фоссрора и калия. Определено, что на фоне уменьшения отношения побочной продукции к зерну сои $(1,5: 1)$ увеличивается вынос азота на формирование как листостебельной массы (в 2,2 раза), так и зерна (на 32 \%). Установлено, что часть биологически фиксированного азота, вынесенного с биологическим урожаем сои с гектара площади, составляет $43 \%$, азот почвы составляет $57 \%$. Для диагностики обогащенности почвы азотом в последействии симбиотической азотфиксации предлагается определять «нетто» азотфиксации по фрактическим запасам минерального азота в почве под инокулированной соей (за минусом его запасов под неинокулированной) и по потенциальному количеству азота, поступающего дополнительно с общей листостебельной массой (по разнице между содержанием азота в листостебельной массе инокулированной и неинокулированной сои). В погодных условиях 2018 года на черноземе типичном «нетто» азотфиксации под соей составило 69 кг N / га, из которых 40 кг / га - запасы минерального азота в почве и 29 кг / га - азот, поступающий с листостебельной массой.

Ключевые слова: азот; инокуляция; запасы минерального азота; развитие растений сои; симбиотическая азотфиксация; чернозём типичный. 